\section{Russia establishes advisory council in bid to boost science}

Bryon MacWilliams, Moscow

President Vladimir Putin has set up a new advisory council to help him revive Russia's beleaguered science and hightechnology sectors.

Scientists hope the body will make science a higher political priority, although they note that it includes many officials who have overseen the free fall in funding and prestige that has made scientists some of the poorest-paid workers in the country.

The Council on Science and High Technology, which comprises 24 politicians and high-ranking science officials, is charged with helping to prioritize policies on science and innovation, as well as drafting legislation. It will meet at least twice a year, and report on developments world wide in science and technology, promote cooperation with foreign scientific organizations, and recommend measures to ensure the welfare of Russian scientists.

In part, the council represents a reac tion to complaints that the Putin administration has failed to address the dire circumstances facing Russia's scientists "Many have criticized us for the insufficient attention we have paid," says Aleksei Gromov, a government spokesman.

Members of the council, headed by Kremlin official Sergei Abramov, wil include Yuri Osipov, president of the Russian Academy of Sciences, Victor Sadovnichii, rector of Moscow State University, and Evgeny Velikhov, president of the Kurchatov Institute in Moscow.

\title{
Academy backing bolsters shaky support for crust study
}

\section{Rex Dalton, Boston}

EarthScope, a major US initiative to study the Earth's crust that has struggled to win government support, has received a strong endorsement from the US National Academy of Sciences.

"EarthScope will have a substantial impact on earth science in America and worldwide," says an academy report released on 8 November. The report was produced by a seven-member panel chaired by George Hornberger, a hydrologist at the University of Virginia in Charlottesville.

Advocates of the $\$ 400$-million project hope the report will nudge the National Science Foundation (NSF) and NASA into incorporating the project in their respective budgets for 2003, which are being prepared and will be released by President George W. Bush in February.

Last year, Congress prevented the Clinton administration from starting EarthScope, and the Bush administration has so far shown little sign of supporting it - although mid-level agency officials are in favour of the plan. "We are doing our best to produce a budget including EarthScope," says Herman Zimmerman, director of the NSF's earthsciences division.

The NSF component of EarthScope would comprise three main elements: a mobile, national grid of seismometers, called USArray; the Plate Boundary Observatory, which would monitor the movement of tectonic plates in the Pacific Northwest; and the San Andreas Fault Observatory at
Depth (SAFOD), which would drill into the fault south of San Francisco (see Nature 405, 390-392; 2000). These would cost a total of about \$200 million over five years. NASA would contribute a further $\$ 200$ million to EarthScope, in the form of an Interferometric Synthetic Aperture Radar (InSAR) satellite, which would monitor land movement.

The American Association of State Geologists, which met in Boston last week, has also endorsed the project, as has the National Science Board, the governing body of the NSF. But supporters of the project remain worried that it may not obtain sufficient political backing.

t www.earthscope.org

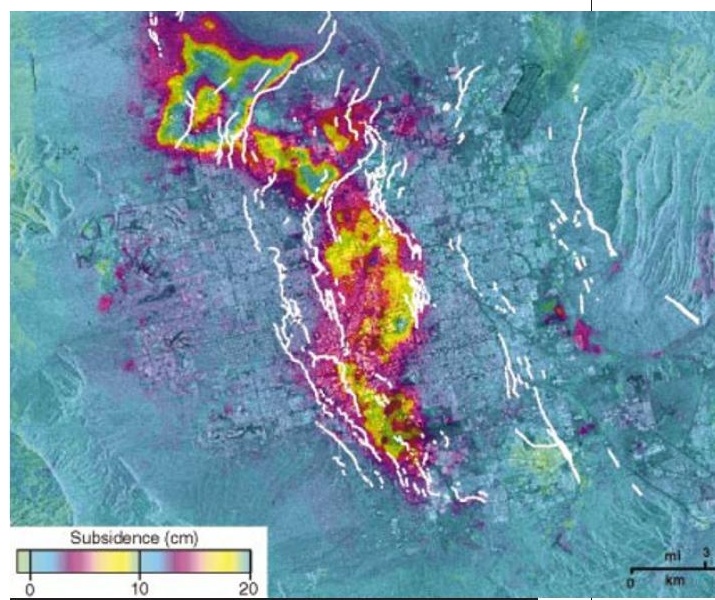

Rock star: EarthScope would combine satellite imaging with ground-based studies.

\section{Harvard squeaks through oncomouse patent appeal}

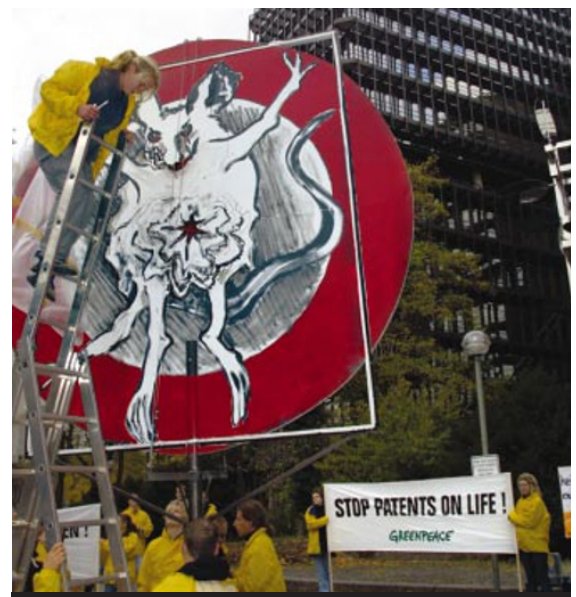

Mouse protest: activist groups opposed the patent on grounds of animal suffering.
Alison Abbott, Munich

The European Patent Office (EPO) has upheld the patent on the Harvard oncomouse, a mouse strain genetically engineered to be susceptible to cancer.

But the patent office has restricted the breadth of the Harvard University patent which currently covers all animals that are genetically engineered using the oncomouse technology - to cover only rodents.

More than 100 organizations and individuals had registered their opposition to the patent, which sparked intense controversy when it came into force in 1992.

"The appeal board felt that it was impossible to assume that the balance between benefit to society and suffering to the mouse could be automatically extended to all types of animals," says
Christian Guggerell, the EPO's spokesman on biopatents.

Opponents of the patent consider this to be a tacit admission of unacceptable animal suffering. "The EPO's position lacks logic, both ethically and legally," says Greenpeace spokesman Christoph Then.

The decision is the first to be made by the EPO on an appeal against an animal patent since it adopted the European Union's 1998 directive on biopatents. A moratorium on patents on life had been in effect for two years before that, as the EPO awaited ethical guidelines from the European Union.

The directive allows such patents to be awarded if the benefit to society is deemed greater than the suffering to the animals. Since the directive was adopted, the EPO has granted 20 further patents on animals. 